\title{
Gene structure and promoter functional analysis of the marmoset type II GnRH receptor
}

\author{
Bjarne Faurholm, Shaun Cochrane, Robert R Millar ${ }^{1}$ and Arieh A Katz \\ MRC/UCT Research Group for Receptor Biology, Institute of Infectious Disease and Molecular Medicine, Faculty of Health Sciences, University of Cape Town, Private Bag X3, Cape \\ Town, Observatory 7925, South Africa \\ ${ }^{1}$ MRC Human Reproductive Sciences Unit, The Queens Medical Research Institute, Little France Crescent, Edinburgh EH16 44TJ, UK \\ (Requests for offprints should be addressed to A A Katz; Email: arieh.katz@uct.ac.za)
}

\begin{abstract}
The marmoset type II GnRH receptor $(G n R H-R)$ gene has the same structure and genomic organisation as the human and other type II GnRH-R genes. The gene consists of three exons and two introns and overlaps in the antisense orientation on its $5^{\prime}$ end with peroxisomal membrane protein $11 \beta$ and on its $3^{\prime}$ end with the RNA-binding motif protein $8 \mathrm{~A}$. However, these genes occur only at one locus in the marmoset genome, while in the human at two loci. Employing $5^{\prime}$ rapid amplification of cDNA ends demonstrated that the marmoset type II GnRH-R gene has two transcriptional start sites at -341 and -567 nucleotides relative to the translational start codon and both start sites lack TATA and CAAT consensus sequences. A luciferase reporter construct with a $2 \cdot 3 \mathrm{~kb} 5^{\prime}$ flanking region of the type II $G n R H-R$ gene was active in a wide variety of cell lines tested, consistent with the wide tissue expression of the receptor. Progressive $5^{\prime}$ and $3^{\prime}$ deletions were employed to identify sequences required for basal expression of the type II GnRH-Rgene. This analysis identified negative regulatory elements in the regions $-2342 /-1995,-1679 /-1084$ and $-458 /-1$ and positive regulatory elements in the regions $-1995 /-1679,-1084 /-458$ and $-458 /-1$ relative to the translational start site. The strongest of the positive regions located between $-766 /-665$ has enhancer activity when cloned in front of a heterologous minimal promoter and is critical for basal expression of the type II GnRH-R.
\end{abstract}

Journal of Molecular Endocrinology (2007) 39, 91-104

\section{Introduction}

Most vertebrate species contain at least two different gonadotrophin-releasing hormone $(\mathrm{GnRH})$ peptides. The first form, designated GnRH I, varies in sequence between species and regulates reproduction through binding to its cognate type I GnRH receptor (GnRH-R) on the pituitary gonadotrophs and controlling the release of luteinizing hormone (LH) and folliclestimulating hormone (FSH; Conn \& Crowley 1994, Millar 2003). The second form, designated GnRH II is structurally conserved in species from bony fish to man, suggesting an important function (King \& Millar 1995, 1997). However, the physiological roles of GnRH II are poorly understood. GnRH II has been implicated in the regulation of gonadotrophin release in several species, regulation of neurotransmission in amphibian sympathetic ganglia and in the regulation of female mating behavior in sparrows, musk shrews and recently also in the marmoset (Maney et al. 1997, Millar 2003, Temple et al. 2003, Barnett et al. 2006).

To date, the type II (GnRH-R) cDNA and gene have been cloned and sequenced only from human (Faurholm et al. 2001, Morgan et al. 2003). In addition, from three monkey species, marmoset (Millar et al.
2001), African green and rhesus (Neill et al. 2001) and from pig (Neill et al. 2004) only the cDNAs encoding the type II GnRH-R have been cloned and sequenced. While, from sheep (Gault et al. 2004), bovine (Morgan et al. 2006) and chimpanzee (GenBank accession number NW_102275.1) only the genes encoding the type II GnRH-R have been sequenced and their coding regions predicted. The type II $G n R H-R$ genes comprise of three exons and have the same gene structure as the type I GnRH-Rs. The marmoset, African green and rhesus monkeys and probably also pig type II GnRH-R genes encode functional receptors. However, the human, chimpanzee, sheep and bovine genes apparently encode non-functional receptors. The human and chimpanzee genes have the same frame shift in exon 1 and a stop codon in exon 2, the sheep gene has a stop codon in exon 1 and a major deletion in exon 2, while the bovine gene has several frame shifts, stop codons and deletions. The primate type II GnRH-Rs have $90-93 \%$ amino acid identity to each other, $80-67 \%$ amino acid identity to the sheep and bovine type II GnRH-Rs respectively and only $41 \%$ amino acid identity to the human type I GnRH-R. As with the type I GnRHRs, the type II GnRH-Rs are seven transmembrane domain receptors that couple to G-proteins of the $\mathrm{G}_{\mathrm{q} / 11}$ 
class. A striking feature of type II GnRH-Rs is the presence of a C-terminal tail, which is important for receptor internalisation, in contrast to the mammalian type I GnRH-Rs, which uniquely lack that region (Ronacher et al. 2004).

The human, sheep and bovine type II GnRH-R genes have been shown to overlap two genes in the antisense orientation. On the $5^{\prime}$ end, the promoter region of the receptor gene overlaps the promoter of the peroxisomal

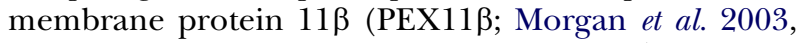
2006, Gault et al. 2004). While on the $3^{\prime}$ end, the sequence encoding the C-terminus of the receptor overlaps the region encoding the C-terminus of the RNA-binding motif protein 8A (RBM8A; Faurholm et al. 2001, Morgan et al. 2003, Gault et al. 2004). However, in humans, in addition to the above-mentioned locus that is located on chromosome 1q.12, there is a second locus encoding the type II $G n R H-R$ gene on chromosome 14q.22. This locus contains exons 2 and 3 of the type II gene flanking on their $3^{\prime}$ end in antisense orientation an intronless RBM8A pseudogene, designated RBM8B and this locus probably originated from the locus on chromosome 1 by retrotransposition.

The type II GnRH-R is widely expressed. The tissue distribution of the primate type II GnRH-R has been investigated by means of RT-PCR, cloning, northern blot and RNA dot blot analysis. The type II GnRH-R is expressed in many areas of the brain including the midbrain, pons and cerebellum, and in several areas of the forebrain including the hypothalamus. In addition, the receptor is expressed in many reproductive tissues including the pituitary, testis, ovary, oviduct, uterus, prostate, breast and placenta, as well as in many nonreproductive peripheral tissues (Faurholm et al. 2001, Millar et al. 2001, Neill et al. 2001, van Biljon et al. 2002, Morgan et al. 2003). The wide expression of the type II GnRH-R contrasts with the limited expression of the type I GnRH-R. The mammalian type I GnRH-R is found primarily in the pituitary and in addition has been detected in placenta, ovary, uterus, breast, prostate, testis and in T-cells (Belisle et al. 1984, Kaiser et al. 1992, Kakar et al. 1992, 1994, Reinhart et al. 1992, Tsutsumi et al. 1992, Chi et al. 1993, Wilson et al. 1995, King \& Millar 1997). The difference in tissue expression of transcripts of the type I and type II GnRH-Rs suggests differences in the transcriptional regulation of the two receptors.

The type II GnRH-R gene encodes a functional receptor in several species including marmoset. Furthermore, the marmoset type II GnRH-R together with its cognate ligand have been implicated in stimulating female marmoset sexual behavior (Barnett et al. 2006). In order to elucidate the transcriptional regulation of the type II GnRH-R, we set in the present study to characterise the gene structure and genomic organisation of the marmoset type II GnRH-R. In addition, we have determined the transcriptional start sites of the gene, have functionally identified several positive and negative regulatory sequences in the $2.3 \mathrm{~kb} 5^{\prime}$ flanking region of the marmoset type II GnRH-R promoter that control the basal expression of the receptor gene and have identified putative cis-regulatory elements in the promoter region.

\section{Materials and methods}

\section{Genomic library screening and Southern blot analysis of genomic clones}

A genomic DNA library (in $\lambda$ vector EMBL3) of a male common marmoset monkey (Callithrix jacchus) was very kindly provided by Prof. Shoji Kawamura, University of Tokyo, Japan. Approximately $2 \times 10^{6}$ plaque-forming units of the library were screened using a randomly ${ }^{32} \mathrm{P}$-dCTP-labelled probe generated by PCR amplification of marmoset type II GnRH-R cDNA (Millar et al. 2001) with primers E1-1F and E3-2R (Table 1). A tertiary screening of the library resulted in three independent positive clones. Liquid lysate was made from two plaques of each positive clone (Ausubel et al. 2001) and DNA was isolated using Nucleobond L-50 (Machery-Nagel, Düren, Germany).

Southern blot was performed on the $\lambda$ DNA clones digested with BamHI, SalI, BamHI-SalI. Blots were hybridised to radiolabelled probes that were PCRamplified from cloned type II GnRH-R cDNA (Millar et al. 2001) with primers to exon $1, \mathrm{P} 6 \mathrm{~F}$ and E1-2R, and for exons 2-3, E2-1F and E3-1R.

\section{PCR analysis of marmoset genomic DNA and $\lambda$ genomic clones}

The presence of exons 2 and 3 on all three $\lambda$ clones was confirmed by PCR with primers E2-1F and E3-1R (Table 1 ). The presence of exon 1 on $\lambda$ clones 1 and 2 and the absence of exon 1 on clone 3 was confirmed by PCR with primers P6F and E1-1R.

Genomic DNA was prepared from marmoset monkey liver (Ausubel et al. 2001). RBM8A was PCR amplified from marmoset and human genomic DNA or from marmoset $\lambda$ DNA clone 3 with primers RE1-F and RE6$1 \mathrm{R}$, which correspond to exons 1 and 6 respectively. PCR between exon 2 of the type II GnRH-R and exon 1 of RBM8A was done with primers E2-1F and RE1-1F for marmoset RBM8A and with primers HE2-2F and RE1$1 \mathrm{~F}$ for human RBM8A. Intron 1 and flanking exons 1 and 2 sequence was PCR amplified from marmoset genomic DNA and from $\lambda$ clone 2 using primers $\mathrm{E} 1-1 \mathrm{~F}$ and E2-2R. The PCR products were partially sequenced with primers E1-2F and E2-1R. Exon 2, Intron 2 and exon 3 sequence was PCR amplified from $\lambda$ clone 3 using primers E2-1F and the vector primer EMBL R. The PCR products were sequenced with primers E2-1F, I2-1F and E3-2R. 
Table 1 Oligonucleotides used in the present study

Sequence $\left(5^{\prime}\right.$ to $\left.3^{\prime}\right)$

ATGTAGCTAGCGGGCTTGGCTCTGAGCACTG ATGTACTCGAGCGTGACTAGGGGCGAGAAGT ATATGGGCCCGCCCCGGCTCGGCGGCC ATATGGGCCCCCTCCTGCGCGACCCAACG ATATGGGCCCAGAAAGCGAGTGGAGCTGGC ATATGGGCCCCCTGTCTTTGAGCCTGTCTGC TATGAATTCATCCTCCTATCTCCAGGC AAGAGTCTCCTGACCGGAGAG TTCCAGGTGGCATCTAGGG CACTGTTCAGTGGCTGGCTGG GTATGCTGCAGCTTTCCTGCC CAGTTCCCTTCACTCAGTGTGC

E2-1F

HE2-2F

$\mathrm{E} 2-1 \mathrm{R}$

$\mathrm{E} 2-2 \mathrm{R}$

I2-1F

E3-1R

E3-2R

RE6-1R

RE1-1F

AP1

AP2

PGL3adapF

PGL3adapR

EMBL $R$

KAN-2 FP-1

KAN-2 RP-1
GCAAGAGACCACCTATAACCT

GGGGCTGGACACACCGAGCA TGGCTCCCCTTCCTTGTCCG

GTGCAAGCTGTCTTCACCAG

CGGGGAAAACCAGTACCACAG

CAAAGGAGCATTGAGGAGGCCA

TTCTGCTGCGTCTTCGGCCA

TGGCGGACGTGCTAGATCTTCA

CCATCCTAATACGACTCACTATAGGGC

ACTCACTATAGGGCTCGAGCGGC

CGGGCCCGATATCCCGGGAATTCTCGAGA

GATCTCTCGAGAATTCCCGGGA-

TATCGGGCCCGGTAC

GTTCATTACTGAACACTCGTCCG

ACCTACAACAAAGCTCTCATCAACC

GCAATGTAACATCAGAGATTTTGAG
Application

$\mathrm{PCR}^{\mathrm{a}}$ conditions

Cloning $100 \mathrm{bp}$ in front of TK promoter

Cloning $100 \mathrm{bp}$ in front of TK promoter

$5^{\prime}$ Deletion of promoter

$5^{\prime}$ Deletion of promoter

$5^{\prime}$ Deletion of promoter

$5^{\prime}$ Deletion of promoter

Southern blot and gene organization

Gene organization and $5^{\prime}$ RACE

Southern blot and $5^{\prime}$ RACE

Southern blot and gene organization

Sequencing

Southern blot, gene organization and

sequencing

Gene organization

Sequencing

Gene organization

Sequencing

Southern blot and gene organization and $5^{\prime}$

RACE

Southern blot, sequencing and $5^{\prime}$ RACE

Gene organization

Gene organization

$5^{\prime}$ RACE

$5^{\prime}$ RACE

Vector adaptor

Vector adaptor

A

A

A

A

A

A

A

$A, B$

$A, B$

A

$\mathrm{n} / \mathrm{a}$

A

A

$\mathrm{n} / \mathrm{a}$

A

$\mathrm{n} / \mathrm{a}$

$A, B$

$A, B$

A

A

B

B

$\mathrm{n} / \mathrm{a}$

Gene organization

Sequencing

Sequencing $\mathrm{n} / \mathrm{a}$

$\mathrm{n} / \mathrm{a}$

$\mathrm{n} / \mathrm{a}$

$n / a$

n/a: not applicable, these oligos were not used in PCR

${ }^{a}$ Two PCR protocols indicated as A or B were employed and their conditions are as follows: A, General PCR: 2 min at $94^{\circ} \mathrm{C},\left(20 \mathrm{~s}\right.$ at $94^{\circ} \mathrm{C}, 30 \mathrm{~s}$ at $60^{\circ} \mathrm{C}$, $1 \mathrm{~min} / \mathrm{kb}$ at $\left.72^{\circ} \mathrm{C}\right) \times 30$ cycles, $5 \mathrm{~min}$ at $72^{\circ} \mathrm{C}$. B, Touchdown PCR (for $\left.5^{\prime} \mathrm{RACE}\right): 2 \mathrm{~min}$ at $94^{\circ} \mathrm{C},\left(20 \mathrm{~s}\right.$ at $94^{\circ} \mathrm{C}, 30 \mathrm{~s}$ at $69^{\circ} \mathrm{C}, 3 \mathrm{~min}$ at $\left.72^{\circ} \mathrm{C}\right) \times 5 \mathrm{cycles},(20 \mathrm{~s}$ at $94^{\circ} \mathrm{C}, 30 \mathrm{~s}$ at $68^{\circ} \mathrm{C}, 3 \mathrm{~min}$ at $\left.72^{\circ} \mathrm{C}\right) \times 5$ cycles, $\left(20 \mathrm{~s}\right.$ at $94^{\circ} \mathrm{C}, 30 \mathrm{~s}$ at $67^{\circ} \mathrm{C}, 3 \mathrm{~min}$ at $\left.72{ }^{\circ} \mathrm{C}\right) \times 25 \mathrm{cycles}, 3 \mathrm{~min}$ at $72^{\circ} \mathrm{C}$.

\section{$5^{\prime}$ Rapid amplification of cDNA ends (5' RACE) on marmoset type II GnRH-R cDNA}

Total RNA was extracted from whole brain of a male marmoset using Tri-Reagent (MRC, Cincinnati, OH, USA) and poly $\mathrm{A}^{+}$RNA was isolated using the PolyATtract mRNA isolation system (Promega) according to the manufacturers' protocols. Marathon cDNA was made from $1 \mu \mathrm{g}$ poly (A) ${ }^{+}$RNA using the Marathon cDNA kit (Clontech) with a random hexamer nucleotide as primer. $5^{\prime}$ RACE was performed on $1 \mu \mathrm{l}$ of a 1:50 dilution of cDNA with adaptor primer AP1 (Clontech) and two gene-specific primers E3-2R or E1-2R, which correspond to exon 3 or 1 respectively. A 1:50 dilution of the above PCR product was amplified using adaptor primer AP2 and nested gene-specific primers E3-1R or E1-1R, which correspond to exon 1 or 3 respectively. The PCR products were cloned into pMOSblue and sequenced with vector primers $\mathrm{T} 7$ and U19 (Amersham Biosciences).

\section{Sequencing of the $5^{\prime}$ flanking region of the marmoset type II GnRH-R}

$\lambda$ clone 1 was digested with Sall-BamHI and a $3 \mathrm{~kb}$ fragment, containing part of exon 1 and the $5^{\prime}$ flanking region, was cloned into pBluescript II SK (-) (Stratagene, La Jolla, CA, USA), yielding clone MtProSK. Transposon insertions were made for sequencing the insert by using the EZ::TN <KAN-2> insertion kit (Epicentre, Madison, WI, USA) according to the manufacturer's instructions. DNA was prepared using NucleoSpin Plasmid (Machery-Nagel) from colonies with the transposon inserted at appropriate places, followed by sequencing of the DNA with transposon primers KAN-2 FP-1 and KAN-2 RP-1 (Epicentre).

\section{Generation of promoter constructs of the marmoset type II GnRH-R}

MtPro $(-2342 /-1)$, containing $2 \cdot 3 \mathrm{~kb}$ of the promoter region between the SalI site and the ATG 
start codon was cloned into the firefly luciferase reporter vector pGL3basic (Promega) in which the multiple cloning site (MCS) had been replaced for the ease of making subsequent deletions. The MCS was replaced with an adaptor made by annealing oligonucleotides PGL3adapF and PGL3adapR containing the restriction sites KpnI, ApaI, EcoRV, SmaI, EcoRI, XhoI and BglII.

Progressive $5^{\prime}$ deletions were made from the $5^{\prime}$ end of MtPro (Fig. 4). MtPro was digested with BstXI, PvuII, StuI, NcoI, SmaI or DraI and the ends of the BstXI and NcoI digests were made blunt with T4 DNA polymerase (Amersham Biosciences). The digests were cut with EcoRI and cloned in EcoRV-EcoRI digested pGL3, yielding constructs $5^{\prime}$ BstxI $(-1995 /-1), 5^{\prime}$ PvuII $(-1679 /-1), \quad 5^{\prime}$ StuI $\quad(-1346 /-1), \quad 5^{\prime} \mathrm{NcoI}$ $(-1084 /-1), \quad 5^{\prime}$ SmaI $(-766 /-1)$ and $5^{\prime}$ DraI $(-458 /-1)$. The nucleotides of the $5^{\prime}$ flanking region are numbered relative to the translational start codon.

$3^{\prime}$ Progressive deletions were made from the $3^{\prime}$ end of MtPro (Fig. 5). Constructs 3'DraI (-2342/-458), $3^{\prime}$ SmaI $(-2342 /-766), 3^{\prime} \mathrm{NcoI}(-2342 /-1084)$, 3'StuI (-2342/-1346), 3'PvuII (-2342/-1679) and $3^{\prime}$ BstxI $(-2342 /-1995)$ were made by digestion of MtPro with BglII, DraI, SmaI, NcoI, StuI, PvuII or BstXI respectively. The digests were then cut with ApaI and cloned in ApaI-SmaI digested pGL3. The $3^{\prime}$ deletion construct 3 'BglII $(-2342 /-197)$ was made by digesting MtPro with BglII and purifying and religating a $7 \mathrm{~kb}$ fragment.

Four constructs, SD1 $(-715 /-1)$, SD2 $(-665 /-1)$, SD3 $(-615 /-1)$ and SD4 $(-565 /-1)$, were made with 50 bp progressive $5^{\prime}$ deletions from the SmaI site (Fig. 6). MtPro was digested with DraI-EcoRI and a $460 \mathrm{bp}$ fragment was purified. Four PCR products were amplified from MtPro with sense primers P2F, P3F, P4F or P5F and antisense primer E1-1R, followed by digestion of the PCR products with ApaI and DraI. The 260, 210, 160 or $110 \mathrm{bp}$ fragments of the digested PCR products were ligated together with the $460 \mathrm{bp}$ DraI-EcoRI fragment of MtProSK into ApaI-EcoRI digested pGL3.

A $100 \mathrm{bp}$ fragment, $(-766 /-665)$ upstream of the ATG, was cloned in front of the heterologous thymidine kinase promoter, upstream of the luciferase reporter gene. The $100 \mathrm{bp}$ region was PCR amplified using the primers $\mathrm{P} 1 \mathrm{~F}$ and $\mathrm{P} 1 \mathrm{R}$ with the full-length promoter construct MtPro as template. The PCR products were purified, digested with NheI and XhoI, gel purified and cloned into NheI-XhoI digested and dephosphorylated pTAL (Clontech) yielding construct $(-766 /-665)$ TK-Luc.

\section{Cell culture and transfections}

COS-7 (African green monkey kidney), HeLa-S3 (human cervical carcinoma), ND7/23 (mouse neuroblastoma $\times$ rat neurone hybrid), PC-3 (prostrate adenocarcinoma), TM3 (mouse Leydig cell) and transmembrane 4(TM4; mouse Sertoli cell) were obtained from ECACC, Salisbury, UK. GT1-7 (mouse hypothalamic neuron) and L $\beta$ T2 (mouse gonadotroph) cell lines were obtained from P Mellon, UCLA San Diego, CA, USA. COS-7, HeLa-S3, GT1-7, ND7/23 and L $\beta$ T2 cells were maintained in Dulbecco's modified Eagle's medium (DMEM) and 10\% fetal calf serum (FCS). PC-3 cells were maintained in Ham's F12 with $10 \%$ FCS. TM3 and TM4 were maintained in Ham's F12, $5 \%$ horse serum and 2.5\% FCS. All cell lines were maintained in the appropriate media containing glutamine $(0.3 \mathrm{mg} / \mathrm{ml})$, penicillin and streptomycin (PS, each 100 units $/ \mathrm{ml}$ ) at $37^{\circ} \mathrm{C}$ and $5 \% \mathrm{CO}_{2}$. Media, sera, glutamine, hormones and antibiotics were all obtained from Sigma.

DNA for transfections was isolated using Nucleobond PC500 maxiprep (Machery-Nagel). In the experiment testing the full-length promoter in various cell lines, cells were plated at a density of 75000 cells/well of a 24-well plate, $24 \mathrm{~h}$ prior to transfection. In the remaining experiments, using HeLa-S3 cells, the cells were plated at 100000 cells/well $4-6 \mathrm{~h}$ prior to transfection. Transfections were performed using FuGene 6 (Roche) according to the manufacturer's instructions. Each marmoset promoter firefly luciferase construct (150 ng/well) was co-transfected with $50 \mathrm{ng} /$ well pRL-TK, a renilla luciferase control reporter vector (Promega). The renilla luciferase, which is under the control of the thymidine kinase promoter, was used to normalise the experimental firefly luciferase data for transfection efficiency. For each well, the DNA for transfection and $0.75 \mu \mathrm{l} \mathrm{FuGene} 6$ were each diluted in $50 \mu \mathrm{l}$ serum-free DMEM. The diluted DNA and the diluted FuGene 6 were combined and incubated for 25-45 min at room temperature before being added to the cells. Each transfection was performed in duplicate. The transfection medium with FuGene 6 and DNA was changed $24 \mathrm{~h}$ after transfection to DMEM with $10 \%$ FCS supplemented with PS and the cells were harvested $48 \mathrm{~h}$ after transfection.

\section{Luciferase assay}

Firefly and renilla luciferase activities were measured using the Dual-Luciferase Reporter Assay System (Promega) on a LuminoSkan Ascent luminometer (Thermo Labsystems, Helsinki, Finland) according to the manufacturers' protocols. In brief, cells were harvested $48 \mathrm{~h}$ after transfection by lysis in $250 \mu \mathrm{l}$ passive lysis buffer for $20 \mathrm{~min}$ at room temperature followed by one freeze-thaw cycle. Lysates were briefly centrifuged before $10 \mu \mathrm{l}$ was loaded onto a 96-well luminometer plate. The luminometer was first set to inject $50 \mu$ l firefly luciferase substrate LARII, followed 
by a $5 \mathrm{~s}$ shake step and $5 \mathrm{~s}$ of measurement after which $50 \mu \mathrm{l}$ Stop \& Glo was injected, followed by a $5 \mathrm{~s}$ shake step and $5 \mathrm{~s}$ of measurement of renilla luciferase activity.

\section{Sequence and data analysis}

All DNA sequence analysis was done using DNAMAN (Lynnon Biosoft, Quebec, Canada). Analysis for potential transcription factor binding sites was done with MatInspector (Genomatix; Quandt et al. 1995).

Each firefly luciferase measurement was normalised to the level of renilla activity. The results were then calculated as fold-change relative to the average level of expression of promoterless pGL3 in each experiment. The data were analysed using ANOVA and Student's $t$-test or Bonferroni's comparison (SAS statistical package, SAS Institute, Cary, NC, USA; PRISM, GraphPad Inc, San Diego, CA, USA), with error bars indicating S.E.M.

\section{Results}

\section{Structure of the marmoset type II GnRH-R gene}

In order to study the gene structure of the marmoset type II GnRH-R, a genomic DNA library of the common marmoset monkey was screened with a cDNA probe encoding the marmoset type II GnRH-R (Millar et al. 2001). Two types of clones were isolated, the first type (clones 1 and 2) containing the $P E X 11 \beta$ gene and exons 1,2 and 3 of the type II GnRH-R gene and the second type (clone 3 ) containing exons 2 and 3 of the type II GnRH-R gene and the RBM8A gene (Fig 1A).

Employing PCR with primers corresponding to exons 1,2 and 3 of the marmoset type II GnRH-R (Millar et al. 2001 and Table 1) and Southern blot analysis with DNA probes to exon 1 or exons 2-3 of the marmoset type II GnRH-R cDNA on the isolated genomic clones of the type II $G n R H-R$ gene and on marmoset genomic DNA indicated that the marmoset monkey type II GnRH-R gene is made of 3 exons and 2 introns (Fig. 1B and $C$ ) and its structure is identical to the structure of the human and other type II GnRH-R genes and to the structure of the mammalian type I $G n R H-R$ genes (Faurholm et al. 2001, Morgan et al. 2003, 2006, Gault et al. 2004, Cheng \& Leung 2005). Sequencing of the PCR product made with primers corresponding to exons 1 and 2 and alignment of the genomic sequence with the cDNA sequence confirmed that intron 1 is located in (TM4) at exactly the same position of intron 1 of the human type I and type II GnRH-Rs genes. Furthermore, the length of intron 1 of the type II GnRH-R gene is $4.2 \mathrm{~kb}$ and is similar to the length of intron 1 of the human type II GnRH-R gene. Sequencing of the PCR product, amplified from the genomic clones using primers corresponding to exons

A
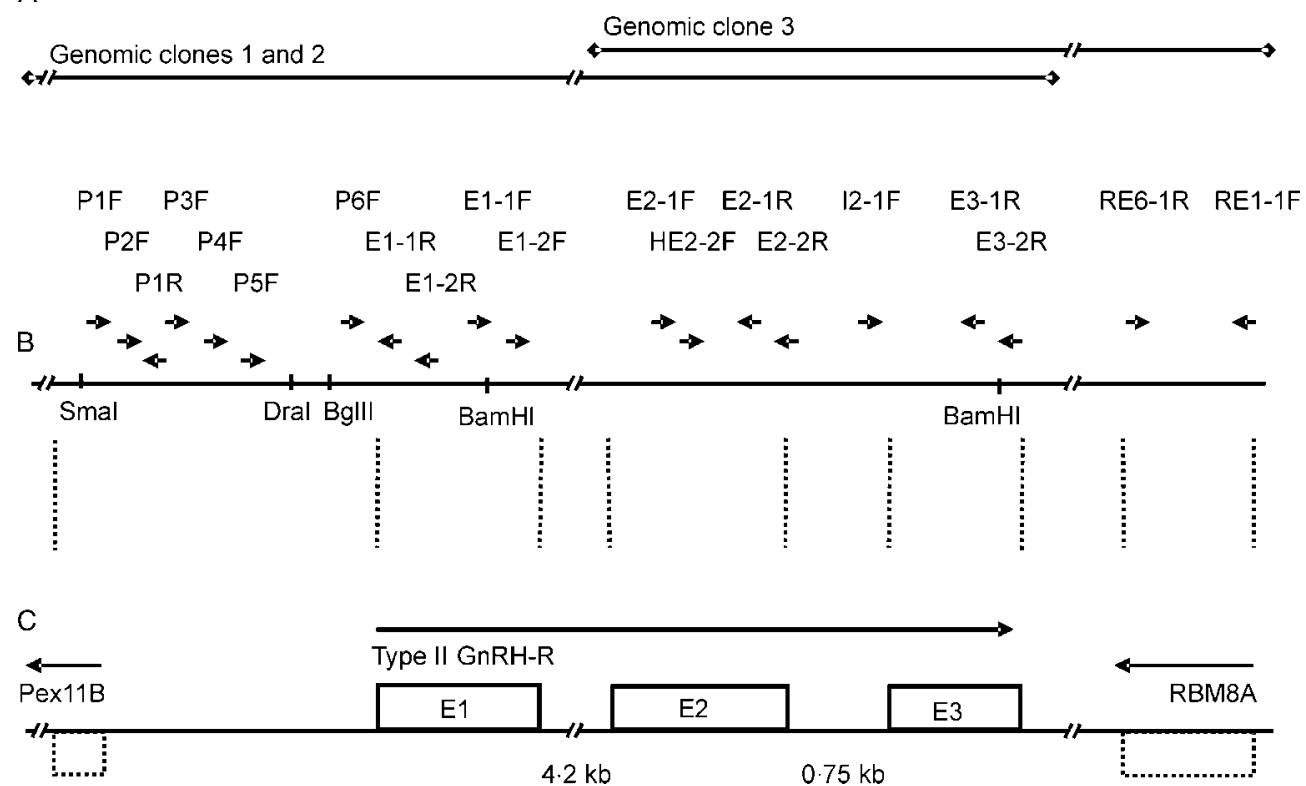

Figure 1 Schematic representation of the marmoset type II GnRH-R gene. (A) Diagram of the genomic clones obtained from library screening. (B) Location of primers used in this study and selected restriction sites. (C) Structure of the marmoset type II $G n R H-R$ gene and locus. Exons of type II $G n R H-R$ gene are indicated by continues line boxes and dotted line boxes indicate $R B M 8 A$ and $P E X 11 \beta$ genes. Arrows indicate the direction of transcription of the type II GnRH-R, RBM8A and PEX $11 \beta$ genes. 
2 and 3 , revealed the presence of a $750 \mathrm{bp}$ intron 2 at the same position, in intracellular loop 3 (ICL 3), as intron 2 in the human type I and type II GnRH-Rs genes. However, the length of this intron is larger than intron 2 of the human type II GnRH-R gene which is $449 \mathrm{bp}$. The exon/intron boundaries of both the introns were sequenced showing that the splice-donor and spliceacceptor consensus sites -gt and -ag are conserved for both introns. These results together show that the gene structure of the type II GnRH-R is identical in marmoset monkeys and humans.

\section{Genomic organisation of the marmoset type II GnRH-R gene}

Sequence analysis of the genomic clone containing the PEX11 $\beta$ gene and exons 1, 2 and 3 of the marmoset type II $G n R H-R$ gene (Fig 1A) indicated that the type II GnRH-R gene overlaps on its $5^{\prime}$ end with the PEX11 $\beta$ gene similar to the organisation of these genes in human, chimpanzee, sheep and bovine (Morgan et al. 2003, 2006, Gault et al. 2004 and GenBank accession number NW_102275.1). Both genes overlap at their promoter region in the antisense orientation and the distance between the ATG start codons of marmoset type II GnRH-R and PEX11 $1 \beta$ genes is 727 nucleotides, similar to the distances found for the human, chimpanzee, sheep and bovine genes.

The genomic organisation of the RBM $8 A$ and type II GnRH-R genes was investigated by PCR analysis and sequencing. PCR between the type II GnRH-R (with primer to exon 2, E2-1F, Table 1) and RBM8A (with primer to exon 1, RE1-1F) genes produced a single band of almost $4 \mathrm{~kb}$ for marmoset genomic DNA and for the marmoset genomic clone that contained both genes (Fig. 2, lanes 2 and 6). As expected, PCR on the marmoset genomic clone that contained PEX11 $\beta$ and the three exons of the type II receptor but lacks the $R B M 8 A$ gene did not give any positive bands (Fig. 2, lanes 3 and 4). Two faint bands are present in lane 3 but the same bands are seen in the negative control (Fig. 2, lane 7 ) indicating that these bands are non-specific. Whereas PCR with the same primers on human genomic DNA produced, as expected, two bands of 3

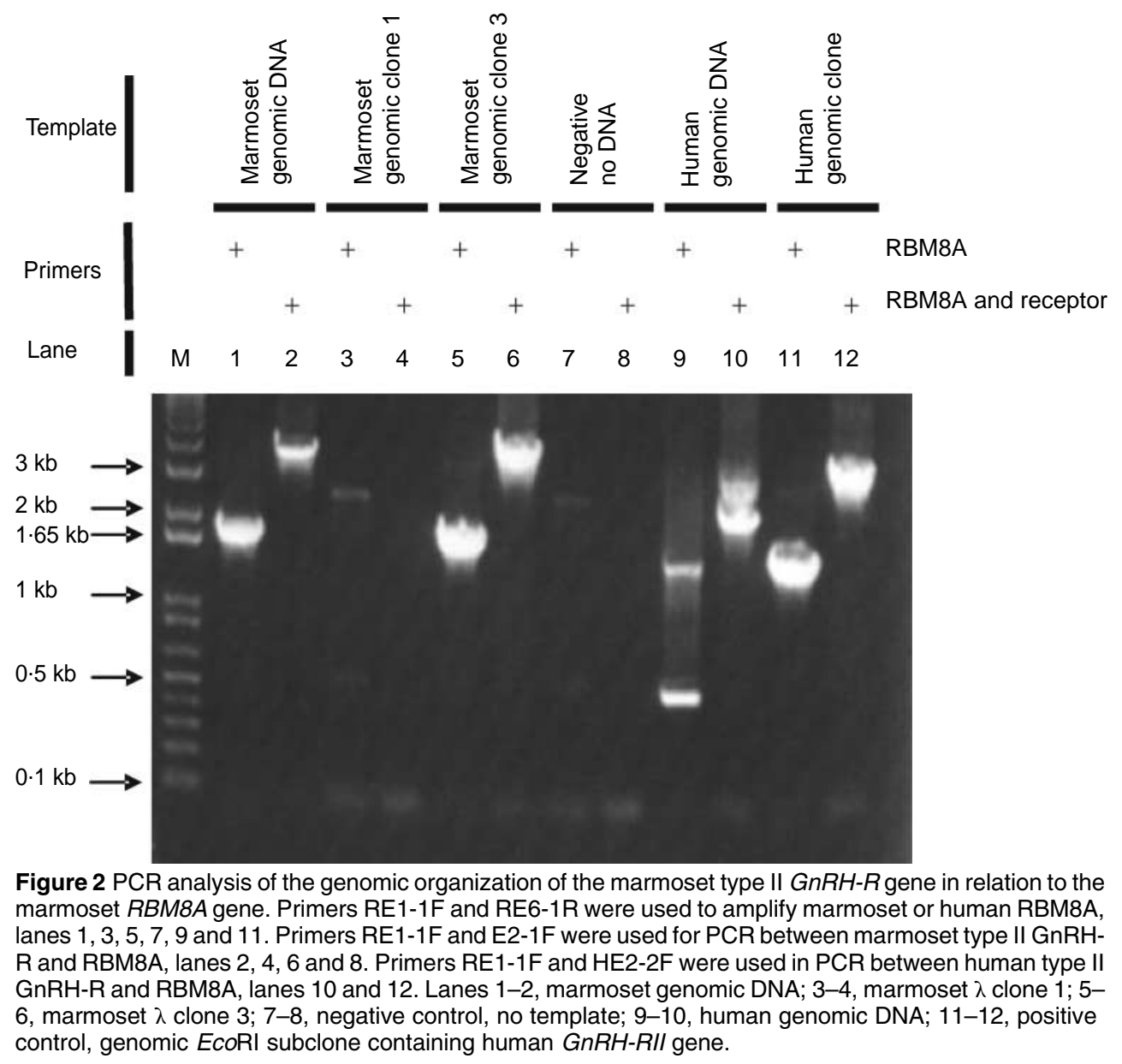


and $2 \mathrm{~kb}$ (Fig. 2, lane 10), corresponding to the two loci encoding type II $G n R H-R$ and $R B M 8 A$ genes on human chromosomes 1 and 14 respectively (Faurholm et al. 2001). The single PCR band with the marmoset DNA shows that both genes exist only in a single locus in the marmoset genome in contrast to the existence of these genes in two loci in the human genome (Faurholm et al. 2001). Furthermore, as in the human, chimpanzee, sheep and bovine genomes, the RBM $8 A$ gene flanks the type II GnRH-R on its $3^{\prime}$ end and both genes are orientated in a tail to tail manner in an antisense orientation (Fig. 1C).

In order to determine the length and organisation of the RBM8A gene, PCR was conducted with primers located at the translational start site in exon 1 (RE1-1F) and the translational termination site in exon 6 of the human RBM8A gene (RE6-1R). PCR on genomic DNA of the marmoset and on the genomic clone that contained exons 2, 3 of the receptor and RBM8A gave a single band of $1.8 \mathrm{~kb}$, in contrast to the two bands of 1.5 and $0.5 \mathrm{~kb}$ obtained for human genomic DNA (Fig. 2 compare lanes $1,5-9)$. The $1.5 \mathrm{~kb}$ band corresponds to the human $R B M 8 A$ gene on chromosome 1 and the $0.5 \mathrm{~kb}$ band corresponds to the intronless human RBM8A pseudogene (designated RBM8B) on chromosome 14 (Faurholm et al. 2001, Morgan et al. 2003). The presence of only one band $(1.8 \mathrm{~kb})$ for marmoset genomic DNA indicates that the marmoset genome contains only one RBM8A gene. These results are consistent with the PCR results mentioned above, employing primers to exons of both genes and indicate that in the marmoset monkey genome the type II GnRH-R and RBM8A genes exist in a single locus and that locus is homologous to the human locus on chromosome 1. In this locus, the type II GnRH-R gene overlaps two genes in the antisense orientation. On the $5^{\prime}$ end, the promoter region of the receptor gene overlaps that of the PEX11 $\beta$. While on the $3^{\prime}$ end, the sequence encoding the $\mathrm{C}$-terminus of the receptor overlaps the region encoding the C-terminus of the RBM8A. This organisation is similar to that found for these genes in humans, chimpanzees, sheep and bovines (Faurholm et al. 2001, Morgan et al. 2003, 2006, Gault et al. 2004 and GenBank accession number NW_102275.1). However, in humans, in addition to the above-mentioned locus that is located on chromosome 1q.12, there is a second locus encoding the type II GnRH-R gene on chromosome 14q.22. The second locus contains a retrotransposed RBM8B pseudogene, flanked by exons 2 and 3 of the type II gene and this locus is absent in the marmoset.

\section{Identification of the transcription start sites (TSSs) of marmoset type II GnRH-R gene}

The location of the TSSs of marmoset type II GnRH-R gene was identified by $5^{\prime}$ RACE on Marathon cDNA from marmoset whole brain using adaptor-specific primers and gene-specific primers to exon 1 or 3 of the marmoset type II GnRH-R (Table 1). Cloning and sequencing of the $5^{\prime}$ RACE products obtained with the exon 1 primer identified a TSS at position -341 relative to the ATG start codon. $5^{\prime}$ RACE utilising an exon 3 primer identified an additional TSS at position -567 relative to the ATG. Interestingly, in the latter transcript, $293 \mathrm{bp}$ of the $5^{\prime}$ UTR was spliced out (nucleotides -472 to -180 relative to the ATG start codon). The spliced-out sequence contained the consensus splice-donor -gt and splice-acceptor -ag sequences suggesting a putative intron. However, in this transcript, the whole of exon 2 was spliced out as well. The coding sequence of exon 1 was immediately followed by exon 3 causing a frameshift. Therefore, this transcript can be regarded as an aberrant transcript that cannot encode a functional receptor but may play a regulatory role in receptor expression.

Analysis of the $2 \cdot 3 \mathrm{~kb} 5^{\prime}$ flanking region of the type II GnRH-R immediately upstream to the ATG indicated that no consensus TATA or CAAT sequences are found in the upstream vicinity of the two identified transcriptional initiation sites.

\section{Functional mapping of promoter sequences required for basal transcription of the marmoset type II GnRH-R gene}

In order to characterise the promoter elements of the type II $G n R H-R$ gene, the $2 \cdot 3$ kb region upstream to the ATG methionine start codon was cloned in front of a promoterless luciferase gene (construct MtPro $(-2342 /-1))$. This construct was transfected into different cell lines in order to determine the presence of promoter activity in the $5^{\prime}$ flanking region and to determine the level of promoter activity in cell lines derived from different tissues. The luciferase measurements (Fig. 3) show a moderate increase in promoter activity of the MtPro construct in TM3 cells (mouse Leydig cells, $3 \cdot 6 \pm 0 \cdot 4$-fold), TM4 cells (mouse Sertoli cells, $3 \cdot 9 \pm 0 \cdot 4$-fold), ND7/23 cells (mouse neuroblastoma $\times$ rat neuron hybrid, $3 \cdot 2 \pm 0 \cdot 26$-fold), GT1-7 cells (mouse hypothalamic neuron, $4 \cdot 6 \pm 0 \cdot 2$-fold), L $\beta$ T2 cells (mouse gonadotroph cells, 2.9 $\pm 0 \cdot 2$-fold) and PC-3 cells (prostrate adenocarcinoma, $2 \cdot 0 \pm 0 \cdot 1$-fold). The largest increases in promoter activity were seen in COS7 cells (African green monkey kidney cells, $8 \cdot 7 \pm 0 \cdot 7$-fold) and in HeLa-S3 cells (human cervical carcinoma cells, $10 \cdot 7 \pm 0 \cdot 9$-fold) which have been shown to express the type II GnRH-R transcripts (Neill et al. 2001). The increase in reporter activity of the marmoset promoter constructs when compared with promoterless control indicates that the $2 \cdot 3 \mathrm{~kb}, 5^{\prime}$ flanking region of the marmoset type II $G n R H-R$ gene has promoter activity in 


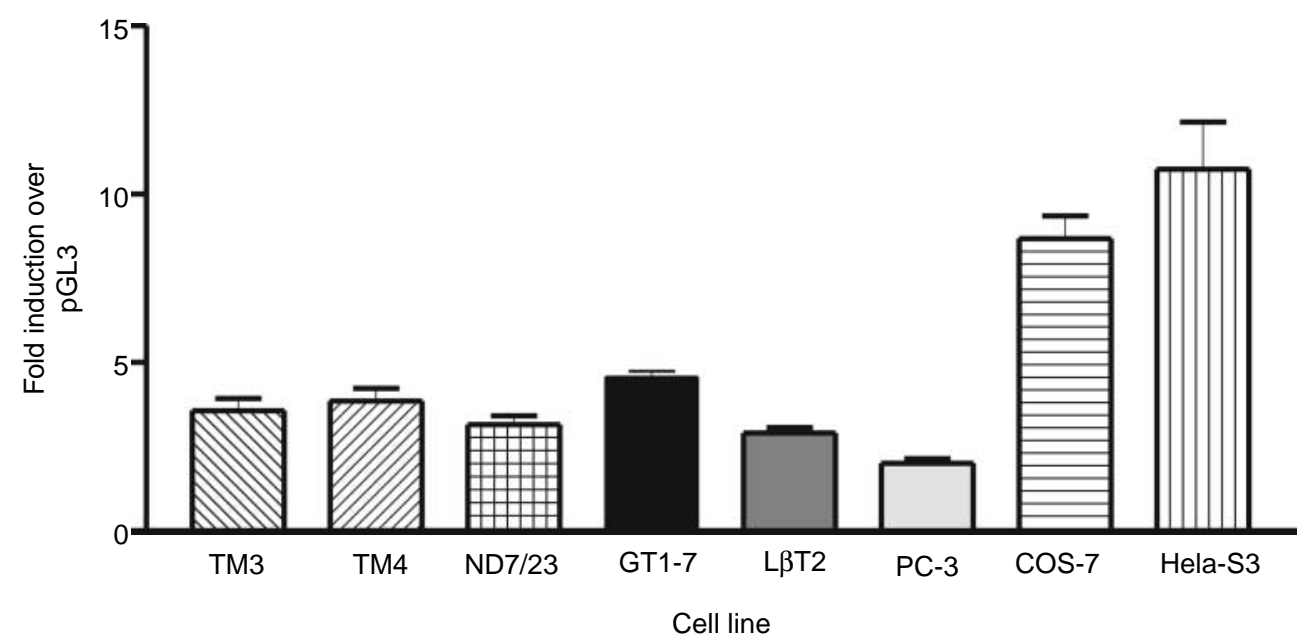

Figure 3 Expression of the marmoset type II GnRH-R promoter in different cell lines. $2.3 \mathrm{~kb}$ of the marmoset type II GnRH-R promoter, cloned in front of firefly luciferase (MtPro $(-2342 /-1)$ ), or the promoterless pGL3 luciferase vector were transiently co-transfected with $\mathrm{pRL}-\mathrm{TK}$ to normalise for transfection efficiency. Luciferase activities were measured $48 \mathrm{~h}$ post-transfection. The firefly luciferase activity was normalised for renilla luciferase activity and the relative promoter activity was calculated as fold induction of MtPro $(-2342 /-1)$ compared to pGL3. The values represent the mean \pm s.E.M. of three independent experiments, each performed in duplicate.

a broad range of cell types and is consistent with the wide tissue distribution of this receptor (Millar et al. 2001).

Progressive $5^{\prime}$ deletions of MtPro were constructed and analysed in HeLa S3 cells in order to map promoter elements that control basal expression in the $2 \cdot 3 \mathrm{~kb} 5^{\prime}$ flanking region of the type II GnRH-R gene (Fig. 4). A deletion of 347 nucleotides at the $5^{\prime}$ end of MtPro increased expression of luciferase when compared with the full-length MtPro (10.8 $\pm 0 \cdot 7$ - and 19.6 $\pm 1 \cdot 1$-fold induction for MtPro and $5^{\prime} \mathrm{BstxI}(-1995 /-1)$ respectively). This increase in expression indicates the presence of a negative regulatory element within the region between nucleotides -2342 and -1995 relative to the translational start codon. A deletion of a further 316 nucleotides to the PvuII site (position - 1679 nucleotides relative to the start codon) resulted in a decrease in expression $(19 \cdot 6 \pm 1 \cdot 1$-fold vs $11 \cdot 9 \pm 0 \cdot 9$-fold induction for constructs $5^{\prime} \mathrm{BstxI}$ and $\left.5^{\prime} \mathrm{PvuII}\right)$, indicating that a positive regulatory element is present in the region between nucleotides -1995 and -1679 . Both the $5^{\prime}$ deletion constructs $5^{\prime}$ StuI $(-1346$ nucleotides) and $5^{\prime} \mathrm{NcoI}(-1084$ nucleotides $)$ showed increases in expression when compared with $5^{\prime}$ PvuII $(25 \cdot 8 \pm 1 \cdot 2$ fold and $34 \cdot 0 \pm 2 \cdot 3$-fold induction for $5^{\prime}$ StuI and $5^{\prime}$ NcoI when compared with $11 \cdot 9 \pm 0 \cdot 9$-fold induction for $5^{\prime}$ PvuII). This result indicates that negative regulatory

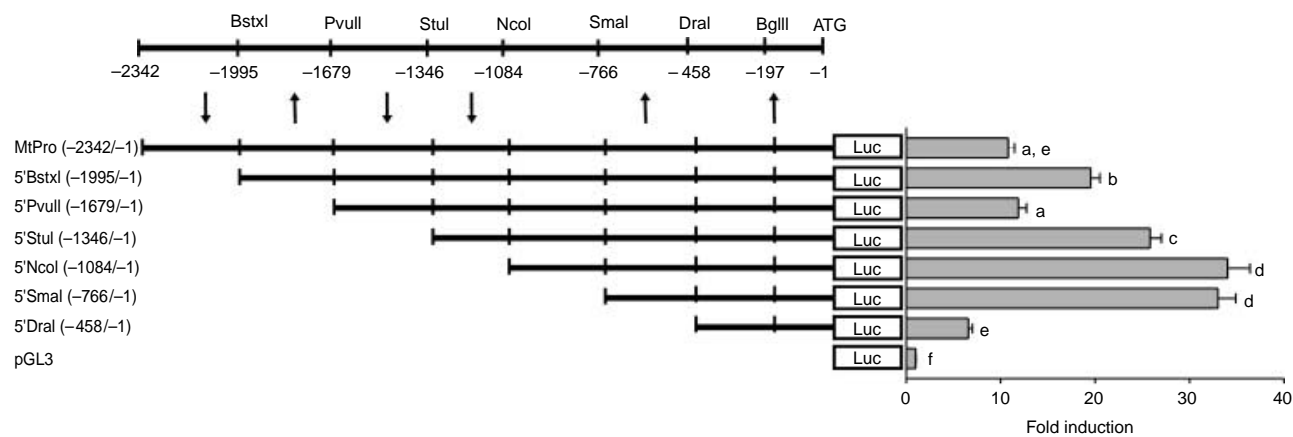

Figure 4 Progressive $5^{\prime}$ deletion analysis of the marmoset type II GnRH-R promoter in HeLa-S3 cells. HeLa cells were transfected with $5^{\prime}$ deletion mutants and co-transfected with $\mathrm{pRL}$-TK in order to normalise for transfection efficiency. The firefly luciferase activity was normalised for renilla luciferase activity and the relative promoter activity was calculated as fold induction compared to promoterless pGL3. The values represent the mean \pm S.E.M. of seven independent experiments, each performed in duplicate. Significant differences between constructs are indicated by different lower case letters to the right of the bars, $P<0 \cdot 01$. The translational start site ATG is indicated. The vertical arrows indicate regions containing positive or negative regulatory elements. 
elements are present in the region between nucleotides -1679 and -1346 and between nucleotides -1346 and -1084 (Fig. 4). The highest expression of the $5^{\prime}$ deletion constructs was obtained for the $5^{\prime} \mathrm{NcoI}$ $(-1084)$ and $5^{\prime}$ SmaI $(-766)$ constructs with $34 \cdot 0 \pm$ 2.3- and $33 \cdot 0 \pm 1 \cdot 9$-fold induction in expression respectively (Fig. 4). This shows that the proximal 766 nucleotides from the SmaI site to the ATG start codon of the marmoset type II GnRH-R gene are sufficient for maximal basal transcription. A further deletion of the region between the SmaI $(-766)$ and DraI $(-458)$ sites showed an $80 \%$ decrease in expression $(6 \cdot 6 \pm 0 \cdot 4-$ fold induction for DraI deletion in comparison to $33 \cdot 0 \pm 1 \cdot 9$-fold induction for SmaI deletion). This result suggests that strong positive regulatory elements are present in this region. The $5^{\prime} \mathrm{DraI}$ deletion construct, which contains 458 nucleotides immediately upstream of the ATG start codon, showed $6 \cdot 6 \pm 0 \cdot 4$-fold induction over the promoterless pGL3. This region is the minimal promoter identified in this study and demonstrates that the proximal 458 nucleotides are sufficient for transcriptional expression of the marmoset type II GnRH-R gene.

Further analysis was done by testing the activity of $3^{\prime}$ deletions of the promoter reporter construct. The $3^{\prime}$ deletion constructs $3^{\prime}$ BglII $(-2342 /-197)$ and $3^{\prime}$ DraI $(-2342 /-458)$ both showed increased activity when compared with full-length MtPro (14.8 $\pm 0 \cdot 9$ - and $36 \cdot 5 \pm 1 \cdot 3$-fold induction for $3^{\prime} \mathrm{BglII}$ and $3^{\prime} \mathrm{Dral}$ when compared with $10 \cdot 8 \pm 0 \cdot 7$-fold induction for MtPro; Fig. 5). The increases in luciferase activity of $3^{\prime} \mathrm{BglII}$ and $3^{\prime}$ DraI may indicate the presence of negative regulatory elements in the regions between the DraI and BglII sites and between BglII and the ATG start codon. Alternatively, the increase in expression may be due to a shorter $5^{\prime}$ UTR, leading to an increase in translation efficiency. A further $3^{\prime}$ deletion to the SmaI $(-766)$ site resulted in an $83 \%$ decrease in luciferase activity (comparing $6 \cdot 2 \pm 0 \cdot 2$-fold induction for $3^{\prime} \mathrm{SmaI}$ with $36 \cdot 5 \pm 1 \cdot 3$-fold induction over pGL3 for $\left.3^{\prime} \mathrm{DraI}\right)$. This result indicates that the region between nucleotides -766 (SmaI site) and -458 (DraI site) contains strong positive promoter element(s) and is consistent with the finding from the $5^{\prime}$ deletions in which deletion of the $-766 /-458$ region resulted in a large decrease in promoter activity (Fig. 4). The subsequent $3^{\prime}$ deletion construct at the NcoI site, lacking the proximal 1084 nucleotides did not direct any luciferase activity indicating that the region between nucleotides -766 and -1084 has positive promoter elements. The remainder $3^{\prime}$ deletion constructs also did not direct any luciferase activity indicating that the net effect of the promoter region upstream to nucleotide -1084 is negative.

Since both the $5^{\prime}$ and $3^{\prime}$ deletion analysis showed that the region between nucleotides -766 and -458 contains strong positive promoter element(s) that are important for basal transcription of the type II GnRH-R gene a more detailed deletion mapping was performed on this region. Primers were designed with $50 \mathrm{bp}$ intervals and PCR amplified fragments were cloned in front of the luciferase reporter gene. The resulting four constructs SD1 $(-715 /-1)$, SD2 $(-665 /-1)$, SD3 $(-615 /-1)$ and SD $4(-565 /-1)$ have $5^{\prime}$ progressive 50 bp deletions in the region downstream of the SmaI site $(-766)$. The $5^{\prime}$ SmaI construct $(-766 /-1)$ and the first deletion construct, SD1 $(-715 /-1)$ directed higher luciferase activity when compared with the full-length MtPro construct (Fig. 6). This is consistent with the previous experiment (Fig. 4) indicating the presence of negative regulatory elements upstream of the SmaI site. The first two deletions, SD1 and SD2, each resulted in a decrease in reporter activity when compared with the $5^{\prime} \mathrm{SmaI}$ construct $(30 \cdot 8 \pm 1 \cdot 9-, 20 \cdot 9 \pm 1 \cdot 4-$ and $11 \cdot 2 \pm 0 \cdot 5$-fold

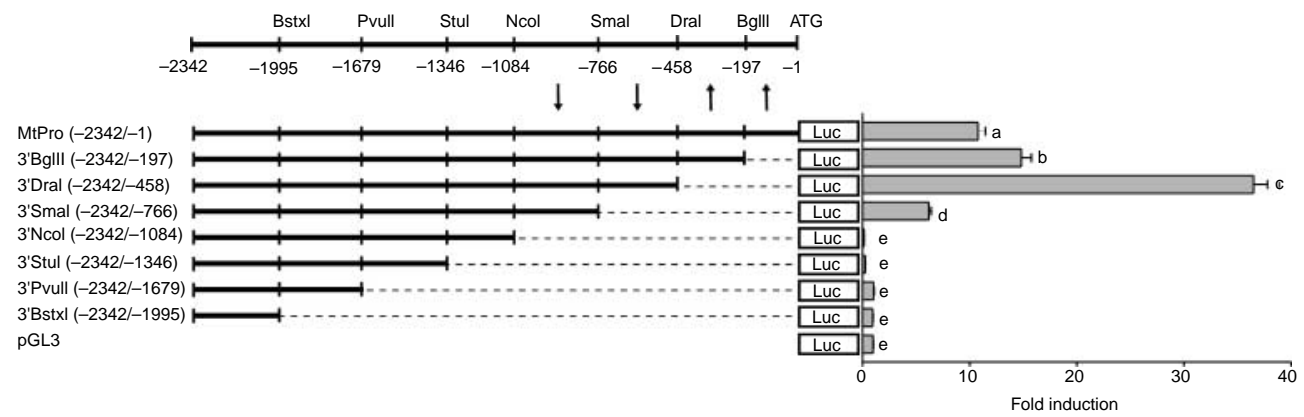

Figure 5 Progressive $3^{\prime}$ deletion analysis of the marmoset type II GnRH-R promoter in HeLa-S3 cells. HeLa cells were transfected with $3^{\prime}$ deletion mutants and co-transfected with $\mathrm{pRL}-\mathrm{TK}$ in order to normalise for transfection efficiency. The firefly luciferase activity was normalised for renilla luciferase activity and the relative promoter activity was calculated as fold induction compared to promoterless pGL3. The values represent the mean \pm S.E.M. of seven independent experiments, each performed in duplicate. Significant differences between constructs are indicated by different lower case letters to the right of the bars, $P<0 \cdot 01$. The translational start site ATG is indicated. The vertical arrows indicate regions containing positive or negative regulatory elements. 


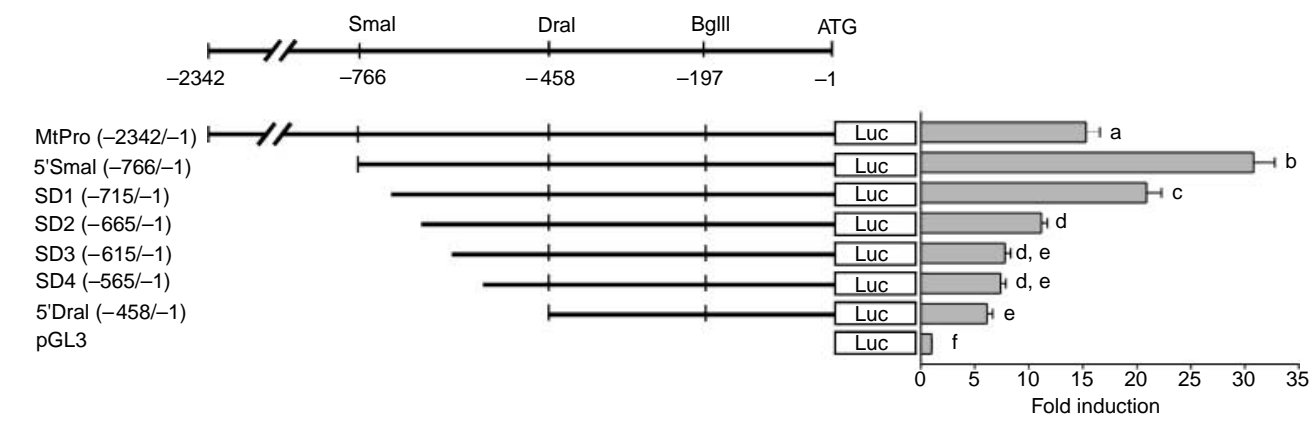

Figure 6 Functional fine-mapping of the -766 to -458 region of the type II GnRH-R promoter. Progressive $5^{\prime}$ deletions of $50 \mathrm{bp}$ were generated in the region between the Smal site $(-766)$ and the Dral site $(-458)$. HeLa cells were transfected with the 50 bp deletion constructs generated together with pRLTK in order to normalise for transfection efficiency. The firefly luciferase activity was normalised for renilla luciferase activity and the relative promoter activity was calculated as fold induction compared to promoterless $p G L 3$. The values represent the mean \pm s.E.M. of six independent experiments, each performed in duplicate.

induction for constructs $5^{\prime}$ SmaI, SD1 and SD2 respectively). The decreases in expression for these two deletions indicate the presence of positive regulatory elements in each of the $50 \mathrm{bp}$ regions between $(-766)$ and $(-665)$. Further $5^{\prime}$ deletions until the DraI site $(-458)$ show only a small decrease in luciferase activity (constructs SD3 $(-615 /-1)$, SD4 $(-565 /-1)$ and $5^{\prime} \mathrm{DraI}(-458 /-1)$ when compared with SD2 $(-665 /-1))$. Therefore, this

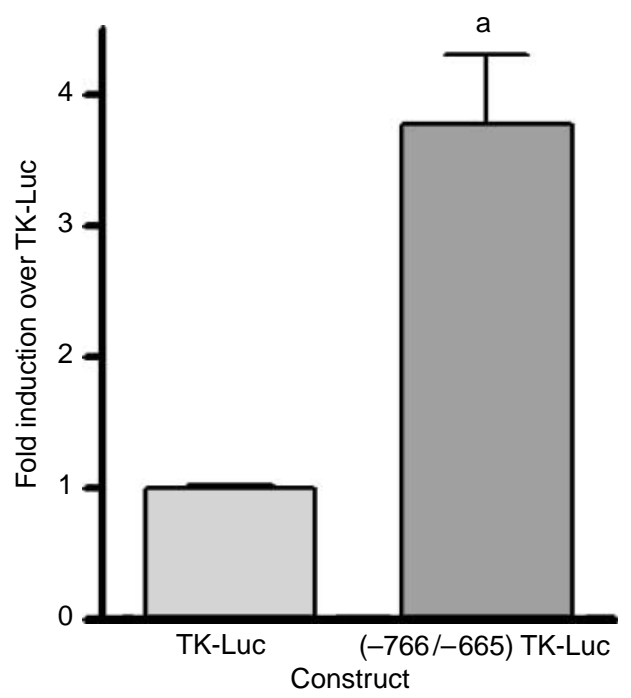

Figure 7 Heterologous stimulation activity of a $100 \mathrm{bp}$ $(-766 /-665)$ region of the marmoset type II GnRH-R promoter. A $100 \mathrm{bp}$ region $(-766 /-665)$ of the promoter was cloned into the expression vector PTAL (TK-Luc) in front of the TK minimal promoter upstream of luciferase, yielding construct $(-766 /-665)$ TK-Luc. The constructs TK-Luc and (766/-665) TK-Luc were co-transfected in HeLa cells with pRL-TK to normalise for transfection efficiency. The activity of the $100 \mathrm{bp}$ region was calculated as fold induction compared to TK-Luc. The values represent the means of three independent experiments, each performed in duplicate; a: $P<0.001$ versus TK-Luc. experiment shows that the $100 \mathrm{bp}$ region between -766 and -665 contains promoter elements which are important for the basal transcription of the marmoset type II GnRH-R gene.

We next tested the enhancer activity of this $100 \mathrm{bp}$ region $(-766 /-665)$ by cloning it in front of a heterologous promoter in order to confirm the importance of this region for basal transcription of the receptor gene. We cloned the $100 \mathrm{bp}$ into the multiple cloning site of pTAL (TK-Luc), which is a reporter construct containing the luciferase gene downstream of the promoter of the Herpes simplex virus thymidine kinase gene, yielding construct $(-766 /-665)$ TK-Luc. The $100 \mathrm{bp}$ region resulted in a significant increase in expression when compared with the vector with thymidine kinase promoter only $(3 \cdot 8 \pm 0 \cdot 5$-fold induction of construct $(-766 /-665)$ TK-Luc when compared with TK-Luc, $P<0 \cdot 001$; Fig. 7 . This confirms that the $100 \mathrm{bp}$ region $(-766 /-665)$ of the marmoset type II GnRH-R promoter has an enhancer activity and is critical for the basal transcription of the receptor gene.

\section{Discussion}

Receptors for the conserved type II GnRH peptide have been cloned from non-primates and primate species including human (Faurholm et al. 2001, Millar et al. 2001, Neill et al. 2001, van Biljon et al. 2002, Morgan et al. 2003, 2006, Gault et al. 2004, Neill et al. 2004). The type II GnRH-R is widely expressed, suggesting different transcriptional control when compared with the type I GnRH-R, which is expressed predominantly in the pituitary.

Isolation and sequencing of the marmoset monkey genomic clone encoding the marmoset type II GnRH-R demonstrated that the gene consists of three exons and 
two introns and having the same structure as the human, chimpanzee, sheep and bovine type II receptors as well as the mammalian type I receptor genes (Fig. 1; Faurholm et al. 2001, Morgan et al. 2003, 2006, Gault et al. 2004, Cheng \& Leung 2005 and GenBank accession number NW_102275.1). Furthermore, the positions of intron 1 in TM4 and intron 2 in ICL3 in these genes are identical and also the splicedonor and splice-acceptor consensus sites -gt and -ag are conserved for both introns. The length of intron 1 is $4 \cdot 2 \mathrm{~kb}$ in both marmoset and human type II GnRH-Rs and is $2.8 \mathrm{~kb}$ in sheep and bovine type II receptors. While the length of intron 2 is $750 \mathrm{bp}$ in the marmoset compared to $449 \mathrm{bp}$ in the human, $631 \mathrm{bp}$ in sheep and $680 \mathrm{bp}$ in bovine type II GnRH-Rs. The identical gene structure of the type I and type II GnRH-Rs indicates a common evolutionary ancestry.

The conservation is not only restricted to the type II $G n R H-R$ gene itself but also to the genes flanking the receptor gene. The type II GnRH gene in marmoset, human, chimpanzee, sheep and bovine is flanked in the antisense orientation by the PEX11 $\beta$ on its $5^{\prime}$ end in a head-to-head orientation and by RBM8A on its $3^{\prime}$ end in a tail-to-tail orientation (Fig. 1; Morgan et al. 2003, 2006, Gault et al. 2004 and GenBank accession number NW_102275.1). On the $5^{\prime}$ end the promoter region of the receptor gene overlaps in the antisense orientation the promoter of the PEX11 $\beta$ and the distance between the ATG start codons of PEX11 $\beta$ and type II GnRH-R is similar in the marmoset, human, chimpanzee, sheep and bovine (727, 705, 703, 754 and $741 \mathrm{bp}$ respectively). While on the $3^{\prime}$ end, the $3^{\prime}$ untranslated region of the receptor overlaps the $3^{\prime}$ untranslated region of the RBM8A (Faurholm et al. 2001, Morgan et al. 2003, Gault et al. 2004). The rat which has a type II gene remnant also has a similar gene arrangement (GenBank Acc. no. AC106482; Pawson et al. 2003), while in mouse, which apparently does not have any remnant of the type II $G n R H-R$ gene, the $P E X 11 \beta$ and RBM8A genes are adjacent, as in other mammals (GenBank accession number AC122037).

In the marmoset monkey genome, the type II $G n R H-R$ is present as a single copy gene and exists in a single locus flanked by PEX11 $\beta$ and $R B M 8 A$ genes as mentioned previously. Similarly, there is apparently a single type II $G n R H-R$ gene locus in the chimpanzee, sheep and bovine genomes (Gault et al. 2004, and GenBank accession numbers NW_102275.1 and NW_931049.1). However, in humans, in addition to the above-mentioned locus that is located on chromosome 1q.12, there is a second locus which has been retrotransposed to chromosome $14 \mathrm{q} 22$ encoding exons 2 and 3 of the type II $G n R H-R$ gene and an intronless RBM8B and this locus is absent in the marmoset, chimpanzee, sheep and bovine. These results indicate that the retrotransposed locus on chromosome 14 in the human genome arose after the divergence of the human and the monkey ancestors.

$5^{\prime}$ RACE identified two TSSs of marmoset type II GnRH-R gene, at positions -341 and -567 relative to the ATG start codon. There is no consensus TATA or CAAT sequences in the upstream vicinity of the two transcriptional initiation sites. The murine type I GnRH-R also does not have these consensus sequences, while the human type I has canonical TATA and CAAT sequences near the transcriptional start sites (Cheng \& Leung 2005). The promoter of the type II GnRH-R is GC rich and the lack of TATA and CAAT sequences is not unusual as many genes encoding GPCRs lack TATA and CAAT sequences and have GC-rich promoter regions (Cheng \& Leung 2005). These two transcriptional start sites were found using brain tissue and it is possible that in other tissues that express the type II GnRH-R, different transcriptional initiation sites are used. While performing $5^{\prime}$ RACE utilising an exon 3 primer a transcript with an alternative spliced transcript was identified. In this transcript, $293 \mathrm{bp}$ of the $5^{\prime}$ UTR was spliced out (nucleotides -472 to -180 relative to the ATG start codon). The spliced-out sequence contained the consensus splice-donor -gt and spliceacceptor -ag sequences suggesting a putative intron. In addition, the whole of exon 2 was spliced out and the coding sequence of exon 1 was immediately followed by exon 3 causing a frameshift. Therefore, this transcript can be regarded as an aberrant transcript that cannot code for a functional receptor but may influence expression of the full-length transcript and/or may encode a truncated protein that can regulate the activity of the full-length receptor protein (Pawson et al. 2005). Alternative splicing that leads to aberrant transcripts is not unusual and has been described for numerous genes including the type II and type I GnRHRs (Grosse et al. 1997, Kottler et al. 1999, Faurholm et al. 2001, Morgan et al. 2003).

In order to characterise the promoter elements of the type II $G n R H-R$ gene required for basal expression, the $2 \cdot 3 \mathrm{~kb}$ region upstream to the ATG methionine start codon was cloned in front of a promoterless luciferase gene (construct MtPro $(-2342 /-1)$ ). This construct directed the expression of the luciferase reporter gene in a variety of cell lines of reproductive, nonreproductive and neuronal tissues. The increase in reporter activity of the marmoset promoter construct when compared with the promoterless control indicates that the $2 \cdot 3 \mathrm{~kb}, 5^{\prime}$ flanking region of the marmoset type II GnRH-R gene has basal promoter activity in a broad range of cell types and is consistent with the wide tissue distribution of this receptor (Faurholm et al. 2001, Millar et al. 2001, Morgan et al. 2003).

Progressive $5^{\prime}$ and $3^{\prime}$ deletion analysis of the marmoset promoter in HeLa S3 cells indicated that multiple positive and negative cis-elements are 
involved in regulating the transcription of the type II GnRH-R gene. This analysis identified four regions $(-2342 /-1995,-1679 /-1346,-1346 /-1084$ and $-458 /-1)$ relative to the ATG start codon with putative negative regulatory elements and four regions $(-1995 /-1679,-1084 /-766,-766 /-458$ and $-458 /-1)$, with positive regulatory elements. However, the putative negative regulatory elements found in the region $-458 /-1$ were identified employing $3^{\prime}$ deletion constructs lacking 197 or 458 nucleotides (Fig. 5) and since the TSSs are at positions -341 and -567 relative to the ATG start codon, the increase in expression of constructs may be due to a shorter $5^{\prime}$ UTR, leading to an increase in translation efficiency. The overall effect of the region upstream to nucleotide -1084 is a negative regulation of expression, as a deletion of the area upstream to nucleotide -1084 results in an increase in expression when compared with the full-length construct MtPro. Consistent with this is the finding that the proximal 766 nucleotides are sufficient for maximal basal transcription. The most important positive regulatory element(s) is located between nucleotides -766 and -458 , since $5^{\prime}$ and $3^{\prime}$ deletions of this region resulted in 80 and $83 \%$ decrease in luciferase expression respectively. A more detailed $5^{\prime}$ progressive $50 \mathrm{bp}$ deletions mapping of this region showed that the $100 \mathrm{bp}$ region between -766 and -665 contains promoter elements which are important for basal transcription of the marmoset type II GnRH-R gene. Furthermore, this region can act as a stand-alone enhancer since it was able to increase expression of the luciferase gene in a context of a heterologous promoter. This confirms that the $100 \mathrm{bp}$ region $(-766 /-665)$ of the marmoset type II GnRH$\mathrm{R}$ promoter is critical for the basal transcription of the receptor gene. Interestingly, this $100 \mathrm{bp}$ displays the highest sequence identity of the $5^{\prime}$ flanking sequences among marmoset, human, chimpanzee, sheep and bovine type II GnRH-R genes (95-82\% identity).

Computer search for putative transcription factor binding sites in the $766 \mathrm{bp}$ region upstream from the ATG start codon on the marmoset, human, chimpanzee, sheep and bovine type II GnRH-R genes showed conservation of a number of putative ciselements which are also conserved in their position relative to the $A T G$ in these genes (Fig. 8). Several of these conserved putative cis-elements including an

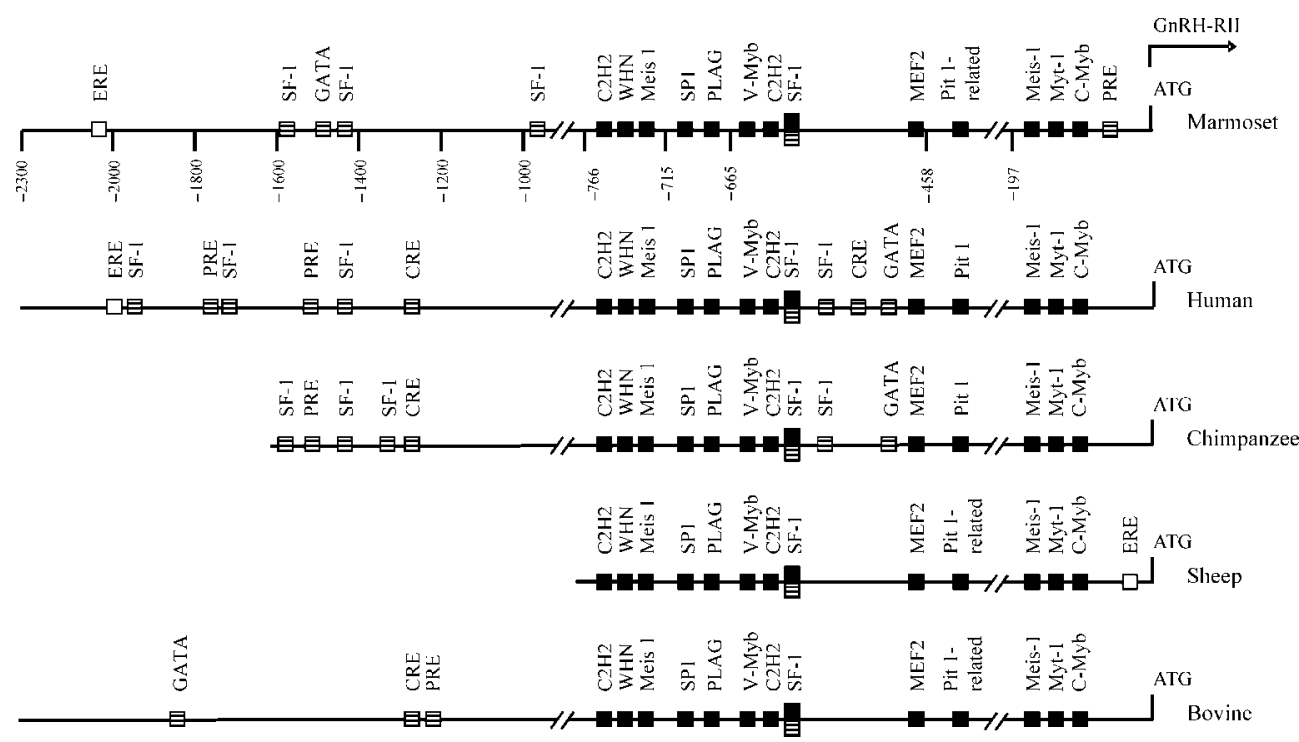

Figure 8 Diagram showing the location of conserved transcription factor (TF) consensus binding sites in the $5^{\prime}$ flanking region of the marmoset, human, chimpanzee, sheep and bovine type II $G n R H-R$ genes. The $766 \mathrm{bp} 5^{\prime}$ flanking region of type II $G n R H-R$ genes depicts TF consensus binding sites identified by MatInspector, while the region upstream to -766 depicts only TF consensus binding sites of PRE, ERE, CRE, GATA and SF-1. TF binding sites conserved in location in marmoset, human, chimpanzee, sheep and bovine type II GnRH-Rs are depicted with filled boxes and TF binding sites not conserved in all indicated type II GnRH-R genes are depicted with empty boxes. Consensus binding sites of TFs important for transcription of the human type I GnRH-R that are conserved in the type II promoters are indicated with striped boxes. TF indicated are: $\mathrm{C} 2 \mathrm{H} 2$, rat $\mathrm{C} 2 \mathrm{H} 2$ zinc finger protein; WHN, winged helix protein; Meis 1, binding site for Meis 1 homeodomain protein; SP1, stimulating protein 1; PLAG, pleomorphic adenoma gene 1; v-Myb, avian myeloblastosis viral oncogene homolog; SF-1, steroidogenic factor 1; CRE, cAMPresponse element; MEF2, myocyte enhancer factor-2; Pit1, pituitary-specific transcription factor; Myt-1, myelin transcription factor; PRE, progesterone receptor response element; ERE, oestrogen receptor response element. This drawing is not to scale. 
element for stimulating protein-1 (SP-1; Kaczynski et al. 2003) are located within the $100 \mathrm{bp}$ region $(-766 /-$ $665)$ that was found to be critical for the receptor gene basal transcription. SP-1 plays a general role in basal expression of many genes that have GC-rich promoters. The promoter of the marmoset type II GnRH-R is GC rich and it is possible that the SP-1 located in the $100 \mathrm{bp}$ region is required for the transcription of the receptor gene.

There is no overall sequence conservation between the $5^{\prime}$ flanking regions of the human type I GnRH-R and the known type II GnRH-R genes. However, several cis-elements are conserved in type I and type II GnRH-R. One element that is conserved is the Pit-1 binding cis-element (AAATATTCAT) present at position $-941 /-934$ of the human type I GnRH-R gene. Pit-1 plays a critical role in pituitary-specific gene expression (Reinhart et al. 1997). This element is present in the human and chimpanzee type II GnRH-R genes, while the marmoset gene, like the sheep and bovine type II GnRH-R genes have a Pit-1 related element, since they retain the first eight nucleotides of the element and differ in the last two nucleotides (AAATATTCCG in marmoset and AAATATTCTG in sheep and bovine). Furthermore, the position of this element in the promoters of the type II genes is very similar (Fig. 8). A second element that is conserved in the type II GnRH-R genes is a putative gonadotroph-specific element (GSE) which is the binding site for steroidogenic factor-1 (SF-1) and mediates expression of the type I GnRH-R as well as the glycoproteins subunits in gonadotrophs (Ngan et al. 1999, Cheng \& Leung 2005). The marmoset promoter has four GSEs, while the other type II GnRH-R genes have between five to a single GSE and a few of them are also conserved in position. A third putative element that is conserved in type I and type II GnRH promoters is the GATA motif. In the human type I GnRH-R, GATA motifs were found to be important for expression in placenta and granulosa cells (Cheng \& Leung 2005). The marmoset, human, chimpanzee and bovine type II GnRH-R promoters have one site each (Fig. 8).

An obvious question is whether the type II $G n R H-R$ gene is regulated by its cognate ligand, GnRH II and by hormones that regulate the type I GnRH-R including GnRH I, progesterone, oestrogen and also by hormones that signal via cAMP (Cheng \& Leung 2005). Screening the $2 \cdot 3 \mathrm{~kb} 5^{\prime}$ flanking region of the marmoset type II GnRH-R gene for consensus transcription factor binding elements showed that this gene has one progesterone receptor response element (PRE) at $(-147 /-142)$, one oestrogen response element (ERE) at $(-2055 /-2046)$ but does not have any cAMP responsive elements (CRE), (Fig. 8). A comparison with the $5^{\prime}$ flanking regions of the human $(2 \cdot 3 \mathrm{~Kb})$, chimpanzee $(1 \cdot 6 \mathrm{~Kb})$, sheep $(0 \cdot 79 \mathrm{~Kb})$ and bovine $(2 \cdot 3 \mathrm{~Kb})$ type II $G n R H-R$ genes showed that at least one PRE is present in each receptor except for sheep (where only $790 \mathrm{bp}$ of $5^{\prime}$ region is known), ERE is present also in the human and sheep type II GnRH-R but not in the chimpanzee and bovine type II GnRH-R genes and in contrast to the marmoset and sheep, the human type II GnRH-R has two CREs, while the chimpanzee and the bovine receptors have a single CRE. Interestingly, several of these elements are conserved in position among the type II GnRH-R genes (Fig. 8).

The conservation in these putative cis-regulatory elements suggests a role in regulation of transcription of the type II $G n R H-R$ genes. However, the possibility that the conservation in these $5^{\prime}$ promoter elements is because they are also part of the PEX11 $\beta$ promoter and gene which overlaps the $5^{\prime}$ end of the type II GnRH-R cannot be excluded.

In conclusion, the marmoset type II $G n R H-R$ gene encodes a functional receptor. Elucidation of the transcriptional start sites, functional mapping of positive and negative promoter regulatory elements and identification of putative cis-regulatory elements set the scene for studies on the basal and hormonal regulation of expression of this receptor, which is expressed in a diversity of tissues.

\section{Acknowledgements}

We would like to thank K Morgan and P Brown for useful discussions and $\mathrm{N}$ Kariem for technical assistance. This work was supported by the Wellcome Trust, UK, the Danish Research Agency and the South African and UK Medical Research Councils. The nucleotide sequence of the marmoset type II GnRH-R gene from -2342 relative to start codon until the start codon has been submitted to the DDBJ/EMBL/GenBank databases under accession number AY676461). The authors declare that there is no conflict of interest that would prejudice the impartiality of this scientific work.

\section{References}

Ausubel FM, Brent R, Kingston RE, Moore DD, Seidman JG, Smith JA \& Struhl K 2001. Current Protocols in Molecular Biology, New York: Wiley.

Barnett DK, Bunnell TM, Millar RP \& Abbott DH 2006 Gonadotropinreleasing hormone II stimulates female sexual behavior in marmoset monkeys. Endocrinology 147 615-623.

Belisle S, Guevin JF, Bellabarba D \& Lehoux JG 1984 Luteinizing hormone-releasing hormone binds to enriched human placental membranes and stimulates in vitro the synthesis of bioactive human chorionic gonadotropin. Journal of Clinical Endocrinology and Metabolism 59 119-126.

van Biljon W, Wykes S, Scherer S, Krawetz SA \& Hapgood J 2002 Type II gonadotropin-releasing hormone receptor transcripts in human sperm. Biology of Reproduction 67 1741-1749. 
Cheng CK \& Leung PC 2005 Molecular biology of gonadotropinreleasing hormone (GnRH)-I, GnRH-II, and their receptors in humans. Endocrine Reviews 26 283-306.

Chi L, Zhou W, Prikhozhan A, Flanagan C, Davidson JS, Golembo M, Illing N, Millar RP \& Sealfon SC 1993 Cloning and characterization of the human GnRH receptor. Molecular and Cellular Endocrinology 91 R1-R6.

Conn PM \& Crowley WF Jr. 1994 Gonadotropin-releasing hormone and its analogs. Annual Review of Medicine 45 391-405.

Faurholm B, Millar RP \& Katz AA 2001 The genes encoding the type II gonadotropin-releasing hormone receptor and the ribonucleoprotein RBM8A in humans overlap in two genomic loci. Genomics $\mathbf{7 8}$ $15-18$.

Gault PM, Morgan K, Pawson AJ, Millar RP \& Lincoln GA 2004 Sheep exhibit novel variations in the organization of the mammalian type II gonadotropin-releasing hormone receptor gene. Endocrinology 145 2362-2374.

Grosse R, Schoneberg T, Schultz G \& Gudermann T 1997 Inhibition of gonadotropin-releasing hormone receptor signaling by expression of a splice variant of the human receptor. Molecular Endocrinology 11 1305-1318.

Kaczynski J, Cook T \& Urrutia R 2003 Sp1- and Kruppel-like transcription factors. Genome Biology 4206.

Kaiser UB, Zhao D, Cardona GR \& Chin WW 1992 Isolation and characterization of cDNAs encoding the rat pituitary gonadotropinreleasing hormone receptor. Biochemical and Biophysical Research Communications 189 1645-1652.

Kakar SS, Musgrove LC, Devor DC, Sellers JC \& Neill JD 1992 Cloning, sequencing, and expression of human gonadotropin releasing hormone (GnRH) receptor. Biochemical and Biophysical Research Communications 189 289-295.

Kakar SS, Grizzle WE \& Neill JD 1994 The nucleotide sequences of human GnRH receptors in breast and ovarian tumors are identical with that found in pituitary. Molecular and Cellular Endocrinology 106 $145-149$.

King JA \& Millar RP 1995 Evolutionary aspects of gonadotropinreleasing hormone and its receptor. Cellular and Molecular Neurobiology 15 5-23.

King JA \& Millar RP 1997 Coordinated evolution of GnRHs and their receptors. In GnRH Neurons: Gene to Behavior, pp 51-77. Eds IS Parhar \& Y Sakuma. Tokyo: Brain Shuppan.

Kottler ML, Bergametti F, Carre MC, Morice S, Decoret E, Lagarde JP, Starzec A \& Counis R 1999 Tissue-specific pattern of variant transcripts of the human gonadotropin-releasing hormone receptor gene. European Journal of Endocrinology 140 561-569.

Maney DL, Richardson RD \& Wingfield JC 1997 Central administration of chicken gonadotropin-releasing hormone-II enhances courtship behavior in a female sparrow. Hormones and Behavior 32 11-18.

Millar RP 2003 GnRH II and type II GnRH, receptors. Trends in Endocrinology and Metabolism 14 35-43.

Millar R, Lowe S, Conklin D, Pawson A, Maudsley S, Troskie B, Ott T, Millar M, Lincoln G, Sellar R et al. 2001 A novel mammalian receptor for the evolutionarily conserved type II GnRH. PNAS 98 9636-9641.

Morgan K, Conklin D, Pawson AJ, Sellar R, Ott TR \& Millar RP 2003 A transcriptionally active human type II gonadotropin- releasing hormone receptor gene homolog overlaps two genes in the antisense orientation on chromosome 1q.12. Endocrinology 144 423-436.

Morgan K, Sellar R, Pawson AJ, Lu Z-L \& Millar RP 2006 Bovine and ovine GnRH-II ligand precursors and type II GnRH receptor genes are functionally inactivated. Endocrinology 147 5041-5051.

Neill JD, Duck LW, Sellers JC \& Musgrove LC 2001 A gonadotropinreleasing hormone $(\mathrm{GnRH})$ receptor specific for $\mathrm{GnRH}$ II in primates. Biochemical and Biophysical Research Communications 282 1012-1018.

Neill JD, Musgrove LC \& Duck LW 2004 Newly recognized GnRH receptors: function and relative role. Trends in Endocrinology and Metabolism 15 383-392.

Ngan ES, Cheng PK, Leung PC \& Chow BK 1999 Steroidogenic factor1 interacts with a gonadotrope-specific element within the first exon of the human gonadotropin-releasing hormone receptor gene to mediate gonadotrope-specific expression. Endocrinology $1402452-$ 2462.

Pawson AJ, Morgan K, Maudsley SR \& Millar RP 2003 Type II, gonadotrophin-releasing hormone (GnRH-II) in reproductive biology. Reproduction 126 271-278.

Pawson AJ, Maudsley S, Morgan K, Davidson L, Naor Z \& Millar RP 2005 Inhibition of human type i gonadotropin-releasing hormone receptor (GnRHR) function by expression of a human type II GnRHR gene fragment. Endocrinology 146 2639-2649.

Quandt K, Frech K, Karas H, Wingender E \& Werner T 1995 MatInd and MatInspector: new fast and versatile tools for detection of consensus matches in nucleotide sequence data. Nucleic Acids Research 23 4878-4884.

Reinhart J, Mertz LM \& Catt KJ 1992 Molecular cloning and expression of cDNA encoding the murine gonadotropin-releasing hormone receptor. Journal of Biological Chemistry 267 21281-21284.

Reinhart J, Xiao S, Arora KK \& Catt KJ 1997 Structural organization and characterization of the promoter region of the rat gonadotropin-releasing hormone receptor gene. Molecular and Cellular Endocrinology 130 1-12.

Ronacher K, Matsiliza N, Nkwanyana N, Pawson AJ, Adam T, Flanagan CA, Millar RP \& Katz AA 2004 Serine residues 338 and 339 in the carboxyl-terminal tail of the type II gonadotropin-releasing hormone receptor are critical for beta-arrestin-independent internalization. Endocrinology 145 4480-4488.

Temple JL, Millar RP \& Rissman EF 2003 An evolutionarily conserved form of gonadotropin-releasing hormone coordinates energy and reproductive behavior. Endocrinology 144 13-19.

Tsutsumi M, Zhou W, Millar RP, Mellon PL, Roberts JL, Flanagan CA, Dong K, Gillo B \& Sealfon SC 1992 Cloning and functional expression of a mouse gonadotropin-releasing hormone receptor. Molecular Endocrinology 6 1163-1169.

Wilson TM, Yu-Lee LY \& Kelley MR 1995 Coordinate gene expression of luteinising hormone-releasing hormone (LHRH) and the LHRH-receptor after prolactin stimulation in the rat $\mathrm{Nb2} \mathrm{T}$-cell line: implications for a role in immunomodulation and cell cycle gene expression. Molecular Endocrinology 9 44-53.

Received in final form 23 April 2007

Accepted 28 May 2007

Made available online as an Accepted Preprint 30 May 2007 